\title{
Effects of acute hypobaric hypoxia on thermoregulatory and circulatory responses during cold air exposure
}

\author{
Sora Shin ${ }^{1}$, Yoshiki Yasukochi ${ }^{2}$, Hitoshi Wakabayashi ${ }^{3}$ and Takafumi Maeda ${ }^{4,5^{*}}$ (D)
}

\begin{abstract}
Background: The thermoregulatory responses during simultaneous exposure to hypoxia and cold are not well understood owing to the opposite reactions of vasomotor tone in these two environments. Therefore, the purpose of this study was to investigate the influences of hypobaric hypoxia on various thermoregulatory responses, including skin blood flow (SkBF) during cold exposure.

Methods: Ten subjects participated in two experimental conditions: normobaric normoxia with cold (NC, barometric pressure $\left(\mathrm{P}_{\mathrm{B}}\right)=760 \mathrm{mmHg}$ ) and hypobaric hypoxia with cold $\left(\mathrm{HC}, \mathrm{P}_{\mathrm{B}}=493 \mathrm{mmHg}\right)$. The air temperature was maintained at $28{ }^{\circ} \mathrm{C}$ for $65 \mathrm{~min}$ and gradually decreased to $19{ }^{\circ} \mathrm{C}$ for both conditions. The total duration of the experiment was $135 \mathrm{~min}$.

Results: The saturation of percutaneous oxygen $\left(\mathrm{SpO}_{2}\right)$ was maintained at $98-99 \%$ in NC condition, but decreased to around $84 \%$ in HC condition. The rectal and mean skin temperatures showed no significant differences between the conditions; however, the forehead temperature was higher in $\mathrm{HC}$ condition than in NC condition. The pulse rate increased in $\mathrm{HC}$ condition, and there was a strong negative relationship between $\mathrm{SpO}_{2}$ and pulse rate $(r=-$ $0.860, p=0.013)$. SkBF and blood pressure showed no significant differences between the two conditions.
\end{abstract}

Conclusion: These results suggest that hypobaric hypoxia during cold exposure did not alter the overall thermoregulatory responses. However, hypobaric hypoxia did affect pulse rate regardless of cold exposure.

Keywords: Cold stress, Altitude, Thermoregulation, Skin temperature, Individual differences

\section{Background}

When the human body is exposed to cold, skin blood flow (SkBF) decreases to minimize the heat loss from the body to the environment [1]. This thermoregulatory adjustment changes skin temperature $\left(\mathrm{T}_{\mathrm{sk}}\right)$, causing it to decline. Further, if the heat storage cannot be maintained, rectal temperature $\left(\mathrm{T}_{\mathrm{re}}\right)$ decreases. However, the thermoregulatory responses during simultaneous exposure to

\footnotetext{
* Correspondence: maeda@design.kyushu-u.ac.jp

${ }^{4}$ Department of Human Science, Faculty of Design, Kyushu University, 4-9-1 Shiobaru, Minami-ku, Fukuoka 815-8540, Japan

${ }^{5}$ Physiological Anthropology Research Center, Faculty of Design, Kyushu University, 4-9-1 Shiobaru, Minami-ku, Fukuoka 815-8540, Japan

Full list of author information is available at the end of the article
}

hypobaric hypoxia and cold are rather equivocal. This stems from the fact that local tissue hypoxia elicits an increase in blood flow in order to maintain the usual oxygen delivery rate for sustained metabolism [2].

Previous studies have shown the changes in $\mathrm{T}_{\mathrm{re}}$ and mean $\mathrm{T}_{\mathrm{sk}}$ during simultaneous exposure to hypoxia and cold. Fukazawa et al. [3] reported no significant differences on $\mathrm{T}_{\text {re }}$, but higher mean $\mathrm{T}_{\text {sk }}$ at $17{ }^{\circ} \mathrm{C}$ and a simulated altitude of $5000 \mathrm{~m}$ compared to normobaric normoxia. Blatteis and Lutherer [4] also found the same results at 10 ${ }^{\circ} \mathrm{C}$ under two different altitudes (3350 and $4340 \mathrm{~m}$ ). In another study, Cipriano and Goldman [5] conducted experiments at three different air temperature $\left(\mathrm{T}_{\text {air }}\right)(15.5$, 
21, and $26.5{ }^{\circ} \mathrm{C}$ ) and two different simulated altitudes (2500 and $5000 \mathrm{~m}$ ). They found lower $\mathrm{T}_{\mathrm{re}}$ at $15.5^{\circ} \mathrm{C}$, but no differences in $\mathrm{T}_{\text {re }}$ at $\mathrm{T}_{\text {air }} 21$ and $26.5{ }^{\circ} \mathrm{C}$ at both altitudes compared to sea level. Higher mean $\mathrm{T}_{\text {sk }}$ was observed when the $\mathrm{T}_{\text {air }}$ was $15.5,21^{\circ} \mathrm{C}$, and has an altitude of $5000 \mathrm{~m}$ compared to sea level. When the $\mathrm{T}_{\text {air }}$ was 26.5 ${ }^{\circ} \mathrm{C}$, no differences on $\mathrm{T}_{\mathrm{re}}$ and mean $\mathrm{T}_{\mathrm{sk}}$ were found at both altitudes compared to sea level.

Some studies have reported regionally different vascular reactions based on changes in $\mathrm{T}_{\mathrm{sk}}$ during hypoxia and thermoneutral environments [6] and increased forearm SkBF during hypoxic exposure in thermoneutral environments $[7,8]$. However, very little research has been conducted on the effects of simultaneous exposure to hypoxia and cold on local responses. Investigating local thermoregulatory responses would help better understanding of physiological responses at high altitudes.

Individual differences should also be noted when investigating physiological responses in hypoxia. Brown et al. [9] have reported that certain subjects showed significantly different $\mathrm{T}_{\text {sk }}$ between hypoxic cold and normoxic cold environments while others did not. Also, previous studies have found genetic polymorphisms that can affect saturation of percutaneous oxygen $\left(\mathrm{SpO}_{2}\right)$ responses in hypoxia and polymorphisms with susceptibility to high-altitude pulmonary edema $[10,11]$.

Therefore, this study aimed to shed light on the effects of hypobaric hypoxia on overall and local thermoregulatory responses during cold exposure and investige individual differences of physiological responses. We hypothesized that (1) regionally different vascular reactions would be observed in hypobaric hypoxia during cold exposure and (2) $\mathrm{SpO}_{2}$ would be different among individuals.

\section{Methods}

\section{Subjects}

Ten male university students participated in this study (mean \pm standard deviation [SD] age $22.7 \pm 1.9$ years; height $174.8 \pm 5.9 \mathrm{~cm}$; body mass $65.3 \pm 7.7 \mathrm{~kg}$ ). All participants were free of cardiovascular, respiratory, and ear diseases. The subjects abstained from alcohol drinking, smoking, and strenuous exercise for the previous 24 $\mathrm{h}$ and were prohibited from taking any food and caffeine for $2 \mathrm{~h}$ prior to their scheduled tests. Written informed consent was obtained from all participants prior to their participation in this study. This research was approved by the Ethics Committee of the Faculty of Design, Kyushu University (Approval number 269).

\section{Experimental design and procedures}

All subjects participated in two experimental conditions: normobaric normoxia with cold (NC) and hypobaric hypoxia with cold (HC). The experimental conditions were randomly distributed, and each condition of a subject was separated by at least $72 \mathrm{~h}$. The subjects wore only undershorts and short-sleeve T-shirts ( 0.13 clo) and they were maintained in a supine position. The total duration of the experiment was $135 \mathrm{~min}$. In both $\mathrm{NC}$ and $\mathrm{HC}$ conditions, the $\mathrm{T}_{\text {air }}$ was maintained at $28{ }^{\circ} \mathrm{C}$ for $65 \mathrm{~min}$ and decreased to $19{ }^{\circ} \mathrm{C}$ for $70 \mathrm{~min}$. Humidity was maintained at $50 \% \mathrm{RH}$ in both conditions. In NC condition, normobaric normoxia (barometric pressure $\left(\mathrm{P}_{\mathrm{B}}\right)$ of $762.0 \pm 2.9($ mean $\pm \mathrm{SD}) \mathrm{mmHg} ; \approx$ sea level $)$ was maintained during the entire experiment. In $\mathrm{HC}$ condition, $\mathrm{P}_{\mathrm{B}}$ was maintained at $764.9 \pm 3.7 \mathrm{mmHg}$ for 30 min and gradually changed to a hypobaric hypoxia environment $\left(\mathrm{P}_{\mathrm{B}}\right.$ of $493.0 \pm 1.5 \mathrm{mmHg} ; 3500 \mathrm{~m}$ altitude) for $30 \mathrm{~min}$, which was maintained until the end of the experiment. We divided the experiment duration into three phases. Phase 1 (P1) $\mathrm{T}_{\text {air }}$ was $28^{\circ} \mathrm{C}$ and $\mathrm{P}_{\mathrm{B}}$ was 760 $\mathrm{mmHg}$ in both conditions. Phase 2 (P2) $\mathrm{T}_{\text {air }}$ was $28{ }^{\circ} \mathrm{C}$ in both conditions, and while $\mathrm{P}_{\mathrm{B}}$ was maintained at 760 $\mathrm{mmHg}$ in the $\mathrm{NC}$ condition, $\mathrm{P}_{\mathrm{B}}$ was decreased from 760 to $493 \mathrm{mmHg}$ in the $\mathrm{HC}$ condition. Finally during phase 3 (P3), $\mathrm{T}_{\text {air }}$ was decreased from 28 to $19{ }^{\circ} \mathrm{C}$ in both conditions and $\mathrm{P}_{\mathrm{B}}$ was $760 \mathrm{mmHg}$ in $\mathrm{NC}$ and $493 \mathrm{mmHg}$ in HC (Fig. 1).

\section{Measurements}

During the entire trial, $T_{\text {re }}$ and $T_{\text {sk }}$ were recorded every 5 s using a data logger (LT-8A, Gram Corporation, Japan). The $\mathrm{T}_{\mathrm{re}}$ was measured using a thermistor probe that was inserted $13 \mathrm{~cm}$ beyond the anal sphincter of the rectum. The $T_{s k}$ was measured by attaching thermistors to the skin corresponding to the following body regions with surgical tape: forehead, chest, forearm, hand, thigh, calf, and instep. Mean $\mathrm{T}_{\text {sk }}$ was estimated using a modified Hardy and DuBois' equation: mean $\mathrm{T}_{\mathrm{sk}}=0.07\left(\mathrm{~T}_{\text {fore- }}\right.$ head $)+0.35\left(\mathrm{~T}_{\text {chest }}\right)+0.14\left(\mathrm{~T}_{\text {forearm }}\right)+0.05\left(\mathrm{~T}_{\text {hand }}\right)+$ $0.19\left(\mathrm{~T}_{\text {thigh }}\right)+0.13\left(\mathrm{~T}_{\text {calf }}\right)+0.07\left(\mathrm{~T}_{\text {foot }}\right)[12] . \mathrm{SkBF}$ on the right proximal third of forearm and the right middle finger pad were measured using a laser doppler flowmeter (Advance Laser Flowmeter ALF21, Advance Company, Ltd., Japan). Pulse rate (PR) and $\mathrm{SpO}_{2}$ were monitored on an earlobe using the pulse CO-Oximetry (Radical-7, Masimo, USA) every $10 \mathrm{~s}$. Blood pressure was measured every 15 min (UA-772K, A\&D Medical, Japan). Shivering was evaluated by subjective responses. The subjects were given a button and were instructed to press the button whenever they felt shivering.

\section{Data analysis}

The $\mathrm{T}_{\text {air }}$ changing rate was 0.15 and $0.13{ }^{\circ} \mathrm{C} \mathrm{min}^{-1}$ in $\mathrm{NC}$ and $\mathrm{HC}$ conditions, respectively. To minimize the effect of the different $T_{\text {air }}$ changing rates, we conducted a data analysis according to the $\mathrm{T}_{\text {air }}$ changes instead of the time changes. Since the $\mathrm{T}_{\text {air }}$ was maintained at $28{ }^{\circ} \mathrm{C}$ during P1 and P2, the average values of $0-30 \mathrm{~min}$ and 


\section{(a) Normobaric normoxia with Cold}

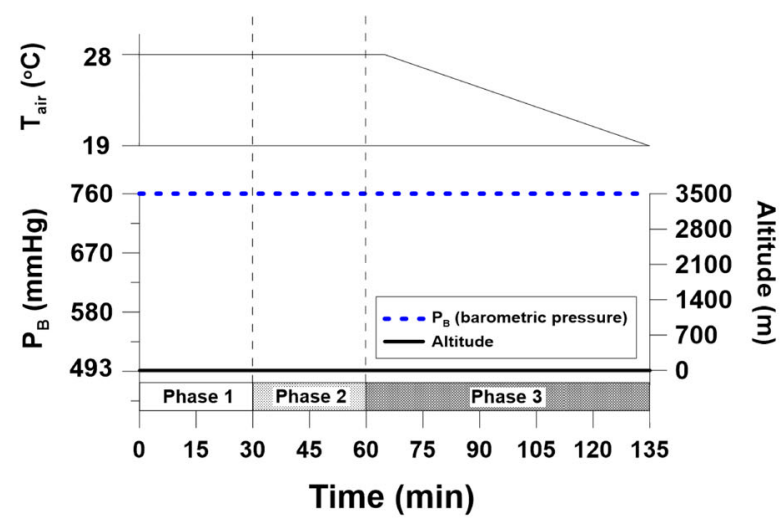

(b) Hypobaric hypoxia with Cold

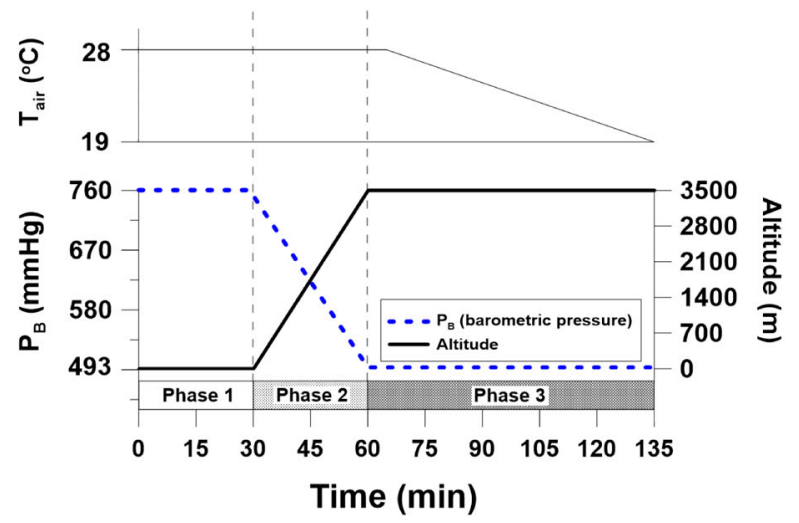

Fig. 1 Experiment conditions of this study. (a) Normobaric normoxia with cold (NC); (b) hypobaric hypoxia with cold (HC). The experiment duration was divided into three phases. Phase 1 (P1) $T_{\text {air }}$ was $28^{\circ} \mathrm{C}$ and $P_{B}$ was $760 \mathrm{mmHg}$ in both conditions. Phase 2 (P2) $T_{\text {air }}$ was $28{ }^{\circ} \mathrm{C}$ in both conditions, and while $P_{B}$ was maintained at $760 \mathrm{mmHg}$ in the NC condition, $P_{B}$ was decreased from 760 to $493 \mathrm{mmHg}$ in the HC condition. Finally during phase 3 (P3), $T_{\text {air }}$ was decreased from 28 to $19 \mathrm{C}$ in both conditions and $\mathrm{P}_{\mathrm{B}}$ was $760 \mathrm{mmHg}$ in NC and $493 \mathrm{mmHg}$ in HC

30-60 min were used as the representative values of P1 and $\mathrm{P} 2$, respectively. For the data of $\mathrm{P} 3$, the average values for every $1{ }^{\circ} \mathrm{C}$ change in $\mathrm{T}_{\text {air }}$ were used. The SkBF values were presented as a percentage of P1. The differences between P1 and P3 of $19-20{ }^{\circ} \mathrm{C}$ were calculated for each condition and expressed as delta values $(\Delta)$. Statistical analyses were performed using SPSS v. 23.0 (IBM SPSS Statistics, USA). A two-way repeated measures ANOVA was run to determine the effect of different conditions over $\mathrm{T}_{\text {air }}$ changes. There was sphericity for the interaction term, as assessed by Mauchly's test of sphericity $(p>0.05)$. One-way repeated measures ANOVA with a Bonferroniadjusted post hoc test was used to establish significant differences over $\mathrm{T}_{\text {air }}$ within a condition. Paired $t$ test was used to compare the difference between $\mathrm{NC}$ and $\mathrm{HC}$ conditions. A Pearson's product-moment correlation was run to assess the relationship between physiological responses. Preliminary analyses showed the relationship to be linear with both variables normally distributed, as assessed by Shapiro-Wilk's test $(p>0.05)$. The significance level was set at $p<0.05$. All data were expressed as mean \pm standard deviation.

\section{Results}

Rectal and skin temperatures

There were no significant differences in $\mathrm{T}_{\mathrm{re}}$ and mean $\mathrm{T}_{\text {sk }}$ during the entire experiment between $\mathrm{NC}$ and $\mathrm{HC}$ conditions (Fig. 2a, b). Forehead temperature in $\mathrm{HC}$
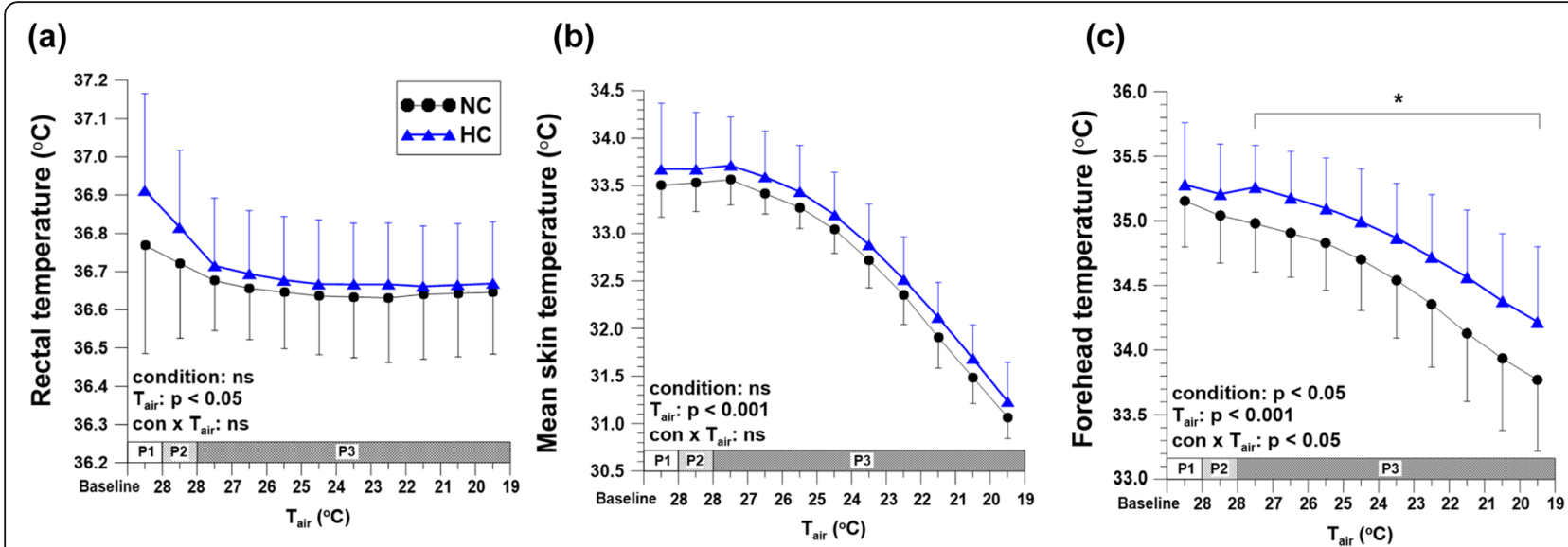

Fig. 2 Rectal temperature (a), mean skin temperature (b), and forehead temperature (c) by air temperature changes in NC and HC. Data were expressed as mean $\pm \mathrm{SD}$. * Significant difference compared between conditions. NC normobaric normoxia with cold; HC hypobaric hypoxia with cold; phase 1 (P1) $\mathrm{T}_{\text {air }}$ was $28^{\circ} \mathrm{C}$ and $\mathrm{P}_{\mathrm{B}}$ was $760 \mathrm{mmHg}$ in both conditions. Phase 2 (P2) $\mathrm{T}_{\text {air }}$ was $28^{\circ} \mathrm{C}$ in both conditions, and while $\mathrm{P}_{\mathrm{B}}$ was maintained at $760 \mathrm{mmHg}$ in the NC condition, $P_{B}$ was decreased from 760 to $493 \mathrm{mmHg}$ in the HC condition. Finally during phase 3 (P3), $T_{\text {air }}$ was decreased from 28 to $19^{\circ} \mathrm{C}$ in both conditions and $P_{B}$ was $760 \mathrm{mmHg}$ in NC and $493 \mathrm{mmHg}$ in HC 
condition was significantly higher than in $\mathrm{NC}$ condition at $\mathrm{P} 3$, and the difference between the conditions was $0.28-0.44{ }^{\circ} \mathrm{C}(p=0.011)$ (Fig. $\left.2 \mathrm{c}\right)$. The other $\mathrm{T}_{\mathrm{sk}} \mathrm{s}$ showed no differences during the entire experiment.

$\mathrm{SpO}_{2}$

$\mathrm{SpO}_{2}$ was maintained at around $98-99 \%$ in NC condition during the entire experiment. In $\mathrm{HC}$ condition, $\mathrm{SpO}_{2}$ was $99.5 \pm 0.4 \%$ at $\mathrm{P} 1$ and significantly decreased to $84.0 \pm 4.3 \%$ at the end of the experiment $(p<$ 0.05) (Fig. 3a).

\section{Pulse rate}

There were no significant differences between two conditions at P1 and P2, respectively. PR in $\mathrm{HC}$ condition increased around $9.4 \pm 4.4 \mathrm{bpm}(p<0.05)$, and it was significantly higher than $\mathrm{NC}$ condition at P3 $(p<0.05)$ (Fig. 3b).

\section{Skin blood flow}

SkBF on the forearm and the finger gradually decreased as the $\mathrm{T}_{\text {air }}$ decreased in both conditions. There were no significant differences in SkBF both on the forearm and finger between $\mathrm{NC}$ and $\mathrm{HC}$ conditions during the entire experiment (Fig. 3c, d).

\section{Blood pressure}

There were no significant differences between $\mathrm{NC}$ and $\mathrm{HC}$ conditions in systolic blood pressure, diastolic blood pressure, and mean arterial pressure, respectively (Table 1).

\section{Subjects perceived shivering}

There were no significant differences in the total number of perceived shivering between $\mathrm{NC}(9.7 \pm 13.6)$ and $\mathrm{HC}(8.6 \pm$ 10.3) conditions $(p=0.838)$.

\section{Relationships among physiological responses}

There was a statistically significant, strong negative correlation between $\Delta \mathrm{SpO}_{2}$ and $\Delta \mathrm{PR}(r=-0.860, p=$ 0.013). Subjects who showed a larger decrease in $\mathrm{SpO}_{2}$
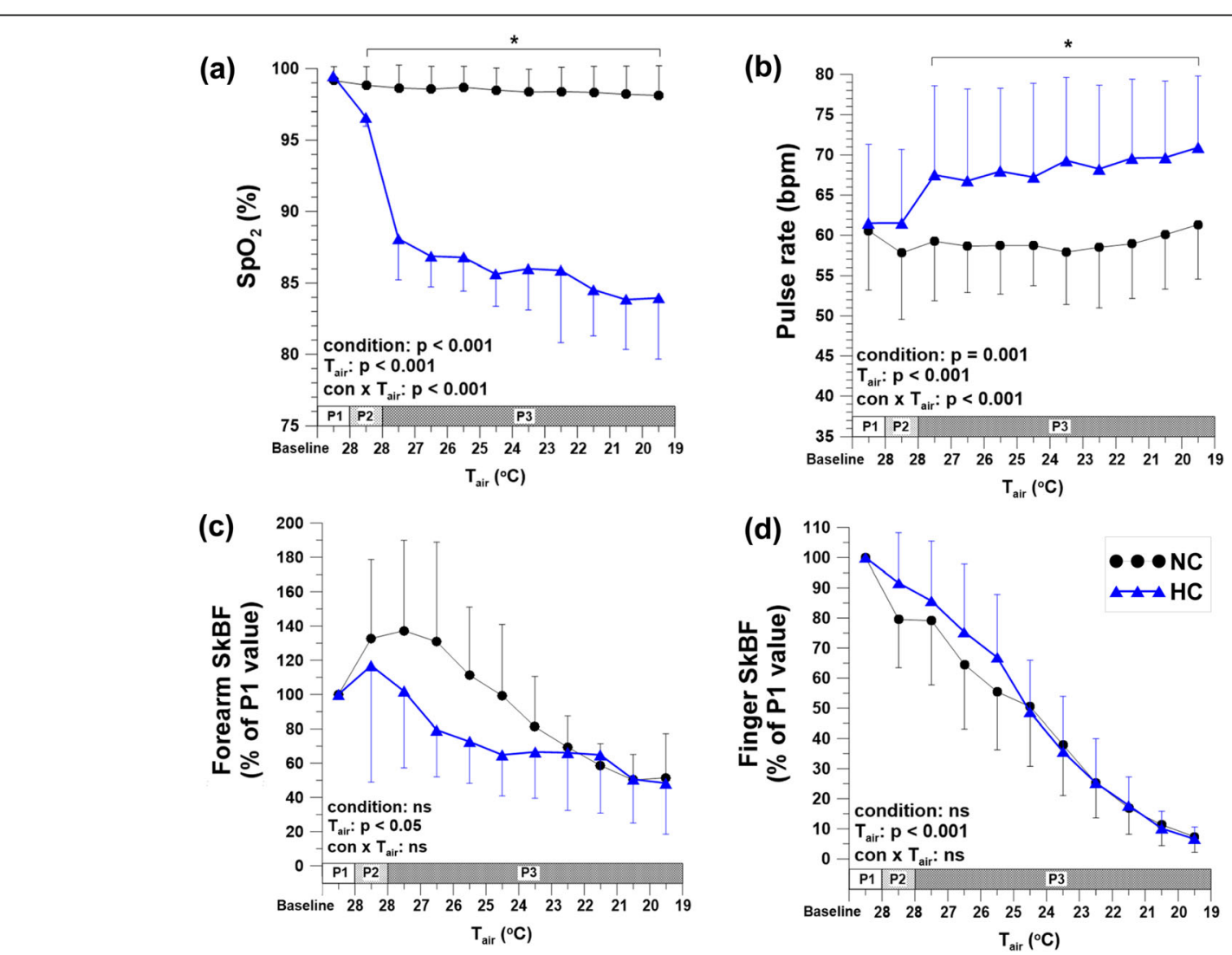

Fig. $3 \mathrm{SpO}_{2}(\mathbf{a})$, pulse rate $(\mathbf{b})$, forearm SkBF $(\mathbf{c})$, and finger SkBF (d) by air temperature changes in NC and HC. Data were expressed as mean \pm $\mathrm{SD}$. The SkBF values are presented as a percentage of P1. *Significant difference compared between conditions. NC normobaric normoxia with cold; $\mathrm{HC}$ hypobaric hypoxia with cold; $\mathrm{SpO}_{2}$ saturation of percutaneous oxygen; SkBF skin blood flow; phase $1(\mathrm{P} 1) \mathrm{T}_{\text {air }}$ was $28^{\circ} \mathrm{C}$ and $\mathrm{P}_{\mathrm{B}}$ was 760 $\mathrm{mmHg}$ in both conditions. Phase 2 (P2) $\mathrm{T}_{\text {air }}$ was $28^{\circ} \mathrm{C}$ in both conditions, and while $\mathrm{P}_{\mathrm{B}}$ was maintained at $760 \mathrm{mmHg}$ in the NC condition, $\mathrm{P}_{B}$ was decreased from 760 to $493 \mathrm{mmHg}$ in the $\mathrm{HC}$ condition. Finally during phase 3 (P3), $\mathrm{T}_{\text {air }}$ was decreased from 28 to $19^{\circ} \mathrm{C}$ in both conditions and $\mathrm{P}_{\mathrm{B}}$ was $760 \mathrm{mmHg}$ in $\mathrm{NC}$ and $493 \mathrm{mmHg}$ in $\mathrm{HC}$ 
Table 1 Mean arterial pressure (MAP) of the NC and the HC conditions

\begin{tabular}{|c|c|c|c|c|c|c|c|c|}
\hline \multirow[b]{2}{*}{ MAP (mmHg) } & \multicolumn{8}{|c|}{ Time (min) } \\
\hline & 30 & 45 & 60 & 75 & 90 & 105 & 120 & 135 \\
\hline NC & $79 \pm 7$ & $80 \pm 5$ & $80 \pm 5$ & $80 \pm 5$ & $83 \pm 5$ & $87 \pm 2$ & $89 \pm 3$ & $92 \pm 6$ \\
\hline $\mathrm{HC}$ & $82 \pm 6$ & $79 \pm 4$ & $81 \pm 7$ & $83 \pm 4$ & $84 \pm 5$ & $86 \pm 6$ & $88 \pm 7$ & $90 \pm 5$ \\
\hline$p$ value & ns & ns & ns & ns & $\mathrm{ns}$ & ns & ns & ns \\
\hline
\end{tabular}

NC normobaric normoxia with cold, HC hypobaric hypoxia with cold

had a larger increase in PR at simulated altitude of 3500 $\mathrm{m}$ (Fig. 4). However, there were no significant relationships for either $\Delta \mathrm{SpO}_{2}$ or $\Delta \mathrm{PR}$ between $\Delta$ mean $\mathrm{T}_{\mathrm{sk}}$, $\Delta \mathrm{T}_{\mathrm{re}}, \Delta \mathrm{T}_{\text {forehead }}$, forearm SkBF, or blood pressure.

\section{Discussion}

There were several principal findings in this study. First, $\mathrm{T}_{\mathrm{re}}$ and mean $\mathrm{T}_{\mathrm{sk}}$ in $\mathrm{HC}$ condition did not significantly differ from those in $\mathrm{NC}$ condition, suggesting that hypobaric hypoxia did not alter overall thermoregulatory responses in cold conditions. Second, the forehead temperature was significantly higher in $\mathrm{HC}$ compared to $\mathrm{NC}$. And third, we found a negative relationship between $\Delta \mathrm{SpO}_{2}$ and $\Delta \mathrm{PR}$, indicating that subjects more vulnerable to hypoxic environments demonstrated a greater burden on the heart.

\section{Rectal and mean skin temperature responses in hypoxia} during cold exposure

Hypoxia is known to affect the cardiovascular system, increasing blood flow and heart rate in order to supply

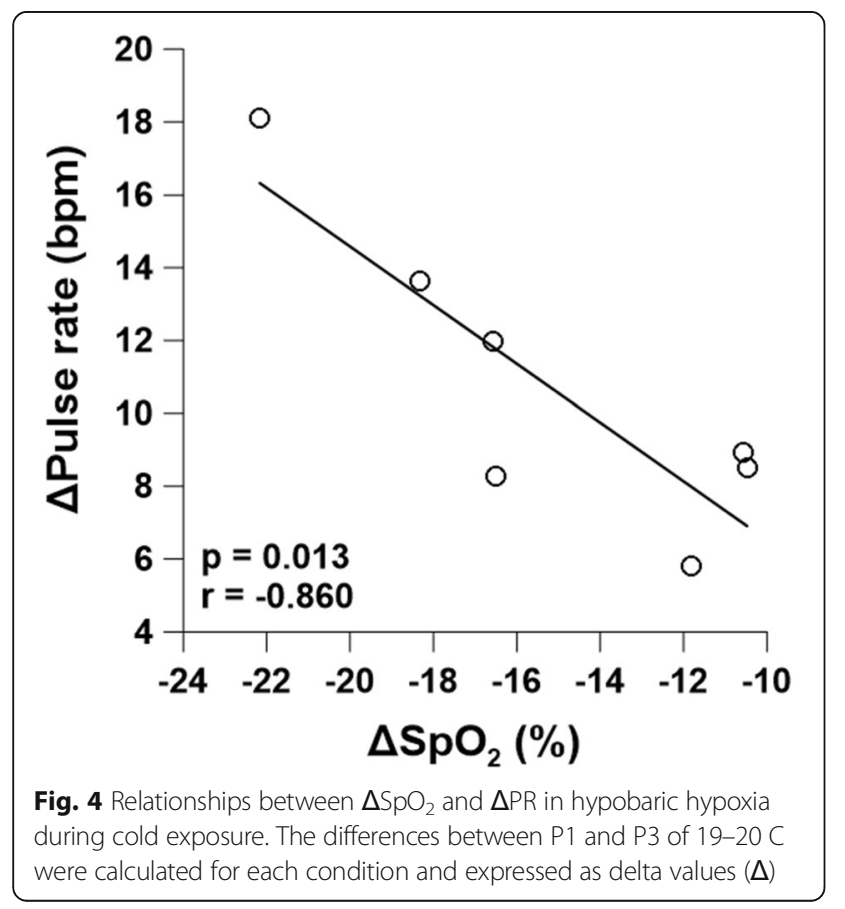

more oxygen to tissues [13]. Nevertheless, we detected no significant effects of hypoxia on $\mathrm{SkBF}$ and $\mathrm{T}_{\text {sk }}$ during cold exposure. There are at least two possible explanations for this observation. First, the levels of hypoxia might have been too mild to induce skin blood vasodilation. Second, hypoxia caused modest local vasodilation in the skin, but the effects of low $\mathrm{T}_{\text {air }}$ suppressed this response, making the overall reaction similar to that observed in normoxia. Either way, heat loss would be indifferent between the $\mathrm{NC}$ and the $\mathrm{HC}$ environments, suggesting that hypobaric hypoxia at the simulated altitude of $3500 \mathrm{~m}(493 \mathrm{mmHg})$ had no significant impact on the changes in $\mathrm{T}_{\mathrm{re}}$ and mean $\mathrm{T}_{\mathrm{sk}}$ during cold exposure.

Forehead temperature in hypoxia during cold exposure In this study, while other local $\mathrm{T}_{\mathrm{sk}} \mathrm{S}$ were not altered by hypobaric hypoxia during cold exposure, forehead temperature was higher in $\mathrm{HC}$ condition than in $\mathrm{NC}$ condition. We were unable to unmask the related mechanisms in this study design. We assumed that this unique response may be related to skin blood vessels on the head or cerebral blood flow since they are anatomically close to each other. Further research is needed to identify the mechanisms related to changes in forehead temperature in hypoxia during cold exposure.

\section{Individual differences in $\mathrm{SpO}_{2}$ and pulse rate}

A strong negative correlation $(r=-0.860)$ between $\triangle \mathrm{SpO}_{2}$ and $\triangle \mathrm{PR}$ was found in this study. The individual differences in $\mathrm{SpO}_{2}$ at high altitudes are well known, and it has been reported in previous studies [14-16]. These individual differences in $\mathrm{SpO}_{2}$ were explained as an aspect of difference in respiratory reflex and genetic polymorphisms $[10,17]$.

Penneys and Thomas [18] have reported a relationship between $\mathrm{SpO}_{2}$ with heart rate and blood pressure, respectively, in normobaric hypoxia without thermal stress. In this study, we only found a relationship between $\mathrm{SpO}_{2}$ and PR. We speculated that this was due to vasoconstriction during cold exposure. The combined results from the previous study and those from this study indicated that blood vessels were more sensitive to cold environments 
than hypoxia, but the heart was directly affected by $\mathrm{SpO}_{2}$ in hypoxia regardless of cold stress.

\section{Conclusion}

We did not find any evidence that hypobaric hypoxia alters overall thermoregulatory responses, but higher forehead skin temperature was observed in hypoxia during cold condition. Also, a negative relationship between $\triangle \mathrm{SpO}_{2}$ and $\triangle \mathrm{PR}$ was found, indicating the subjects more vulnerable to hypoxic environments had a greater burden on the heart. These findings can be applied to alpine climbers and military personnel who are acutely exposed to hypobaric hypoxia under cold stress.

\section{Abbreviations}

NC: Normobaric normoxia with cold; HC: Hypobaric hypoxia with cold $\mathrm{P}_{\mathrm{B}}$ : Barometric pressure; P1: Phase 1; P2: Phase 2; P3: Phase 3; SkBF: Skin blood flow; $T_{s k}$ : Skin temperature; $T_{\text {re: }}$ Rectal temperature; $T_{\text {air }}$ : Air temperature; $\mathrm{SpO}_{2}$ : Saturation of percutaneous oxygen; MAP: Mean arterial pressure

\section{Acknowledgments}

We are grateful to participants for their voluntary contribution in this study. We also acknowledge Mr. M Fujiwara, a research technologist at Kyushu University, for technical assistance.

\section{Authors' contributions}

Takafumi Maeda (TM) conceived, designed research, and edited the manuscript. Sora Shin (SS) conducted experiments, analyzed the data, and wrote the paper. Yoshiki Yasukochi (YY) and Hitoshi Wakabayashi (HW) designed the research and provided critical feedback. All authors read and approved the final manuscript.

\section{Funding}

This work was supported by JSPS KAKENHI Grant Number $18 \mathrm{H} 02518$.

\section{Availability of data and materials}

The datasets used and/or analyzed during the current study are available from the corresponding authors on reasonable request.

\section{Ethics approval and consent to participate}

This research was approved by the Ethics Committee of the Faculty of Design, Kyushu University (Approval number 269). Written informed consent was obtained from all participants prior to their participation in this study.

\section{Consent for publication}

Not applicable.

\section{Competing interests}

The authors declare that they have no conflict of interest.

\section{Author details}

'Graduate School of Design, Kyushu University, 4-9-1 Shiobaru, Minami-ku, Fukuoka 815-8540, Japan. ${ }^{2}$ Department of Human Functional Genomics, Advanced Science Research Promotion Center, Mie University, 1577 Kurima-machiya, Tsu, Mie 514-8507, Japan. ${ }^{3}$ Faculty of Engineering, Hokkaido University, N13 W8, Kita-ku, Sapporo, Hokkaido 060-8628, Japan. ${ }^{4}$ Department of Human Science, Faculty of Design, Kyushu University, 4-9-1 Shiobaru, Minami-ku, Fukuoka 815-8540, Japan. ${ }^{5}$ Physiological Anthropology Research Center, Faculty of Design, Kyushu University, 4-9-1 Shiobaru, Minami-ku, Fukuoka 815-8540, Japan.
Received: 14 April 2020 Accepted: 16 August 2020

Published online: 10 September 2020

\section{References}

1. Maeda T. Relationship between maximum oxygen uptake and peripheral vasoconstriction in a cold environment. J Physiol Anthropol. 2017;36:42.

2. Cabrales P, Tsai AG, Intaglietta M. Nitric oxide regulation of microvascular oxygen exchange during hypoxia and hyperoxia. J Appl Physiol. 2006;100: 1181-7.

3. Fukazawa T, Tochihara Y, Takahara Y. Different impacts of normobaric/ hypobaric hypoxia on physiological and subjective responses at a cold environment. J Human-Environment Syst. 2013;16:011-9.

4. Blatteis CM, Lutherer LO. Effect of altitude exposure on thermoregulatory response of man to cold. J Appl Physiol. 1976;41:848-58.

5. Cipriano LF, Goldman RF. Thermal responses of unclothed men exposed to both cold temperatures and high altitudes. J Appl Physiol. 1975;39:796-800.

6. Golja P, Tipton MJ, Mekjavic IB. Communications: skin temperature responses to hypoxia. J Physiol. 2002;539P:S148.

7. Sagawa S, Shiraki K, Konda N. Cutaneous vascular responses to heat simulated at a high altitude of 5,600 m. J Appl Physiol. 1986;60:1150-4.

8. Minson CT. Skin Blood Flow and Temperature Regulation. In: Roach RC, Wagner PD, Hackett PH, editors. Hypoxia through the lifecycle. Boston: Springer; 2003. p. 249-62

9. Brown AL, Vawter GF, Marbarger JP. Temperature changes in human subjects during exposure to lowered oxygen tension in a cool environment. J Aviat Med. 1952:23:456-63.

10. Yasukochi $Y$, Nishimura T, Motoi M, Watanuki S. Association of EGLN1 genetic polymorphisms with $\mathrm{SpO}_{2}$ responses to acute hypobaric hypoxia in a Japanese cohort. J Physiol Anthropol. 2018;37:9.

11. Yang Y, Du H, Li Y, Guan W, Tang F, Ga Q, et al. NR3C1 gene polymorphisms are associated with high-altitude pulmonary edema in Han Chinese. J Physiol Anthropol. 2019;38:4.

12. Hardy JD, Dubois EF. The technic of measuring radiation and convection. J Nutr. 1938;15:461-75.

13. Heinonen I, Boushel R, Kalliokoski K. The circulatory and metabolic responses to hypoxia in humans - with special reference to adipose tissue physiology and obesity. Front Endocrinol. 2016;7:116.

14. Saito S, Tanobe K, Yamada M, Nishihara F. Relationship between arterial oxygen saturation and heart rate variability at high altitudes. Am J Emerg Med. 2005;23:8-12.

15. Kanai M, Nishihara F, Shiga T, Shimada H, Saito S. Alterations in autonomic nervous control of heart rate among tourists at 2700 and $3700 \mathrm{~m}$ above sea level. Wilderness Environ Med. 2001;12:8-12.

16. Saito S, Shimada H, Imai T, Futamata Y, Yamamori K. Estimation of the degree of acclimatization to high altitude by a rapid and simple physiological examination. Int Arch Occup Environ Health. 1995;67:347-51.

17. West JB, Hackett PH, Maret KH, Milledge JS, Peters RM, Pizzo CJ, et al. Pulmonary gas exchange on the summit of Mount Everest. J Appl Physiol Respir Environ Exerc Physiol. 1983;55:678-87.

18. Penneys $R$, Thomas $C B$. The relationship between the arterial oxygen saturation and the cardiovascular response to induced anoxemia in normal young adults. Circulation. 1950;1:415-25.

\section{Publisher's Note}

Springer Nature remains neutral with regard to jurisdictional claims in published maps and institutional affiliations.
Ready to submit your research? Choose BMC and benefit from:
- fast, convenient online submission
- thorough peer review by experienced researchers in your field
- rapid publication on acceptance
- support for research data, including large and complex data types
- gold Open Access which fosters wider collaboration and increased citations
- maximum visibility for your research: over $100 \mathrm{M}$ website views per year
At BMC, research is always in progress.
Learn more biomedcentral.com/submissions 